\title{
DAS POSSIBILIDADES E NECESSIDADES DO MOMENTO SOCIAL BRASILEIRO - UM PAPEL PARA A REVISTA DE ESTUDOS CULTURAIS
}

POR LUIZ MENNA-BARRETO'

JEFFERSON AGOSTINI MELLO

Percebemos um crescente constrangimento no meio acadêmico com as repetidas profissões de fé produzidas pela nova equipe dirigente do país. Para além do humor, do tipo do que nasce em goiabeiras, há uma situação ambivalente nesse cenário: se, por um lado, essas manifestações primam pela aversão ao debate, por outro, elas convidam a reflexões sobre suas origens e finalidades.

É nesse cenário que divulgamos o quarto número da Revista de Estudos Culturais. Nossa expectativa é a de que ela sirva de inspiração para debates e eventualmente atitudes coletivas. Se a atual onda conservadora pode vir a produzir contradições que inviabilizem o arco de alianças que sustenta o poder, isso requererá, da parte da resistência, respostas imediatas e comprometimentos diversos, como, por exemplo, a promoção de debates capazes tanto de aprofundaro entendimento das raízes do conservadorismo brasileiro, quanto de propor alternativas.

Importa, pois, superarmos o fatalismo pessimista, que nada mais é do que a aceitação peremptória desse ambiente cultural rasteiro e eivado de preconceitos. O rancor dominante nos discursos tanto da equipe dirigente quanto de parte de seu eleitorado já vinha se desenhando há alguns anos. Embora ele tenha óbvias raízes

\footnotetext{
'Mestre e doutor em Ciências (Fisiologia Humana) pela Universidade de São Paulo em 1981, com PósDoutorado na Université de Franche-Comté, França em 1987. Livre-Docente pela Universidade de São Paulo em novembro de 2008 e Titular em 2009. Foi professor do departamento de Fisiologia e Biofísica do Instituto de Ciências Biomédicas da USP entre 1980 e 2005 e, desde 2005 é docente da Escola de Artes, Ciências e Humanidades da USP.

${ }^{2}$ Graduado em Letras pela Universidade Federal de Santa Catarina (1996), mestre em Literatura pela Universidade Federal de Santa Catarina (1999), doutor em Letras (Teoria Literária e Literatura Comparada) pela Universidade de São Paulo (2004) e Livre-Docente na área de Artes, Cultura e Lazer - especialidade Estudos Culturais e Literatura Brasileira. É professor associado da Escola de Artes, Ciências e Humanidades (EACH) da Universidade de São Paulo.
} 
internacionais, seu núcleo duro é local - digamos que colhemos o que deixamos de plantar, ao achar que o resultado do jogo estava a nosso favor, isto é, a favor das aspirações democráticas e progressistas. Mas o jogo só termina quando acaba e cada um o joga com as armas que tem; no nosso caso, isto é, no caso da universidade pública e gratuita, a análise e a reflexão, traduzidas em discurso crítico.

Assim, o texto que abre este número, "Mães negras em luto: configurações da literatura e da crítica literária diante da violência racista", de autoria de Fabiana Carneiro da Silva, discute os limites entre a ética e a estética, apostando no romance Um defeito de cor, de Ana Maria Gonçalves, e na tradição da literatura afrodescendente, que o constitui, como uma forma de se posicionar tanto no campo literário, dominado por um cânone secular (branco e predominantemente masculino) quanto em uma sociedade racista como a nossa, que, neste momento, volta a expor as suas garras sem nenhum pudor. Trata-se, pois, seguindo as palavras da autora, de sublinhar os vínculos entre os modos de representação da maternidade negra, na literatura de autoria negra no Brasil, e o repertório crítico de outras áreas do saber, evidenciando-se aspectos do racismo à brasileira.

O artigo na sequência, "O cansaço como nova categoria de análise para os estudos críticos da deficiência", de Marcos Cezar de Freitas, aponta para um problema de ordem global, mas que compõe um quadro bizarro, ao se associar com o conservadorismo local. Porque aquele que capitaneia o país é justamente aquele que traz em seu séquito representantes do espírito neoliberal, promotores do empreendedorismo de si, de alta performance, a antagonizar a diversidade e a diferença. De acordo com o autor, que constrói seu argumento a partir da análise da obra de Byung-Chul Han, "estaríamos mergulhando numa sociedade do cansaço, provida de uma neuro-enhancement, ou seja, convencidos de que melhoramentos cognitivos decorreriam da exacerbação constante do desempenho neoliberal, que se finge de liberdade enquanto exige 'superar a si mesmo' como única regra [...]". Em outras palavras, no estado de laissez-faire que de agora em diante se faz vigente, somos os únicos culpados do nosso fracasso, em uma condenação perversa e a priori da vítima.

De sua parte, a contribuição de Mathilde Chatin, como artigo "Lula's Brazil in 
Africa: cultural diplomacy as an instrument of soft power", nos traz, pelo contraste, uma percepção da gravidade da mudança em curso no plano cultural. Se, nos dias que correm, a "brutalidade jardim" (para usar uma expressão tropicalista da década de 1970) é articulada, junto com o anti-intelectualismo da hinterlândia que lhe é peculiar, à subserviência aos modelos dos Estados Unidos em sua versão trumpista, Chatin nos mostra como a política externa brasileira, em sua dimensão cultural e educacional, viveu momentos interessantes há poucos anos, em sua opção clara pelas relações internacionais Sul-Sul. Mesmo que justificada, também, por interesses comerciais, "na administração de Lula, a diversidade cultural, que era um dos investimentos principais da diplomacia cultural, torna-se um elemento central para diminuição das assimetrias internacionais resultantes de modelos hegemônicos". Ou seja, se lermos com atenção os dados e reflexões trazidos pela autora, ficará evidente a radicalidade da mudança do Brasil no plano cultural, com a ascensão da direita extremista.

Finalizando a seção de artigos, lemos o ensaio de Diósnio Machado Neto, "Do outro lado da ópera: as bandas como fator de expressão dos núcleos de pertencimento dos imigrantes, na virada do século XX". Com amplo uso de fontes documentais, o autor lê as bandas musicais, surgidas a partir da imigração italiana no Brasil, como articuladoras de "espaços de múltiplos sentidos: da ópera à política; da música à construção das identidades sociais legitimadas; das árias das óperas que percorriam o interior paulista à música caipira de Cornélio Pires". Articuladas, elas próprias, pelo movimento migratório, as bandas forjam, na perspectiva do autor, "não só um elo com um repertório tido como 'civilizador'-a ópera e a música 'oficial' da Igreja-, mas se criou uma transculturação de linguagens que abriu caminhos para manifestações diversas do universo musical regional, principalmente de São Paulo [...]". O fecho da seção, portanto, provoca o leitor, outra vez, ao exercício do contraste, entre, de um lado, a mescla, a transculturação, em uma tentativa-vã - de se forjar uma identidade de um povo imigrante, e, de outro lado, um novo tipo de universalismo - religioso - que este descendente de imigrantes italianos tenta, agora, nos enfiar goela abaixo.

O número termina com uma longa entrevista com Catherine Walsh, concedi- 
da especialmente para a nossa revista. Segundo Iván David Sanabria e Lennon Matos, discentes do Programa de Estudos Culturais, que a entrevistaram, Walsh conduz uma pesquisa cujo trabalho "tem tido como foco, principalmente, o projeto político, epistêmico, ético e existencial da interculturalidade crítica e da decolonialidade, tomando como eixos centrais a geopolítica do conhecimento, a ancestralidade e filosofias de vida-existência, a educação, o pensamento feminista, e as lutas em torno da ideia de gênero, a interculturalidade jurídica, o pensamento e pedagogia decoloniais de resistência, insurgência e re-existência". Perspectivas, como vemos, antagônicas à agenda política e cultural do país nos dias de hoje. Para se ter uma ideia, em uma passagem, Walsh diz: "Entre a extrema-direita no Brasil, Argentina e Colômbia, a consolidação do neoliberalismo no Chile, Peru e novamente no Equador, e os progressismos autoritários da Bolívia e o que Zibechi chamov em 2017 de a "Iuta sem quartel" na Venezuela (ZIBECHI, 2017), a colonialidade se reconstitui de maneira mais complexa, entretecendo-se com as cabeças velhas, novas e que renascem do que as/os zapatistas chamam de a Hidra do capital (EZLN, 2015). O extrativismo é o indício mais inquestionável. Menos falado e estudado é o que se refere aos campos de pensamento, conhecimento e educação. Nisso, a aliança Estado-empresa religiosa exerce um novo poder estratégico fundamental. Seu eixo: 'a ideologia de gênero imposta pela nova ordem mundial'. No Paraguai, Uruguai, Chile, Brasil, Argentina, Colômbia e Peru, e também Bolívia e Equador, o extermínio 'sexo-genérico' está em plena operação [...]".

Essa é mais uma das tarefas da Revista de Estudos Culturais em tempos sombrios, que a entrevista de Walsh corrobora: não baratear o perigo, dizendo o(s) seu(s) nome(s). 